Check for updates

Cite this: RSC Adv., 2017, 7, 22086

Received 2nd March 2017

Accepted 3rd April 2017

DOI: $10.1039 / \mathrm{c} 7 \mathrm{ra02561k}$

rsc.li/rsc-advances

\section{Acute and chronic effects of roxarsone on biological nitrogen and phosphorus removal and its mechanism $\uparrow$}

\author{
Weijiang Huang, Shengjin Sun, Zhao Gao, Yu Chen and Lin Wu (D) *
}

\begin{abstract}
Roxarsone is often used in livestock and poultry feed and is discharged into wastewater treatment plants after consumption. The potential toxicity of roxarsone to activated sludge in wastewater treatment plants has been attracting increasing concern. However, the acute and chronic toxicities of roxarsone to biological nutrient removal (BNR) have never been reported in the literature. In this paper, the potential effects of short-term and long-term exposure to different concentrations of roxarsone in the range of $0-120 \mathrm{mg} \mathrm{L}^{-1}$ on the performance of BNR were investigated. The experimental results show that shortand long-term exposure to low concentrations of roxarsone $\left(0-30 \mathrm{mg} \mathrm{L}^{-1}\right)$ had a negligible influence on nitrogen and phosphorus removal. However, a high concentration of roxarsone $\left(120 \mathrm{mg} \mathrm{L}^{-1}\right)$ seriously inhibited biological phosphorus removal and denitrification. Mechanistic investigations suggested that the high concentration of roxarsone was capable of inhibiting the synthesis and subsequent oxidation of intracellular polyhydroxyalkanoate, which reduced the efficiencies of aerobic phosphorus uptake and denitrification. Further study showed that high concentrations of roxarsone could inhibit the activities of key enzymes and reduce the relative abundance of microorganisms responsible for BNR.
\end{abstract}

\section{Introduction}

Recently, organoarsenic compounds such as roxarsone and arsanilic acid have been widely used as feed additives in animal husbandry because organoarsenic compounds have the advantages of improving livestock resistance to disease, improving feed conversion rate, and promoting animal growth. ${ }^{\mathbf{1} 2}$ In China, the amount of organoarsenic additives used is huge; it was reported that the arsenic content in chicken manure can be as high as $21.6 \mathrm{mg} \mathrm{kg}^{-1}$, and its content in pig manure can reach $83.9 \mathrm{mg} \mathrm{kg}^{-1}$. $^{3}$ Roxarsone (4-hydroxy-3nitrobenzenearsonic acid), a commonly used animal feed additive, contains as ion and organic functional groups. Roxarsone is widely used in the broiler production industry at levels of $20-50 \mathrm{mg} \mathrm{kg}^{-1} \cdot \mathrm{A}^{4,5}$ Livestock and poultry can not digest roxarsone, and it is excreted unchanged in manure. ${ }^{6}$ The widespread use of organoarsenic additives will eventually result in the additives entering into environmental water bodies through runoff and animal wastewater, causing severe environmental risks. $^{6}$

The activated sludge process is one of the most widely used techniques in wastewater treatment plants (WWTPs) to remove nutrients via aggregation, settling, precipitation, biosorption,

School of Tropical and Laboratory Medicine, Hainan Medical University, Haikou, 571101, P. R. China. E-mail: yfdong112@126.com

$\dagger$ Electronic supplementary information (ESI) available: This file contains Fig. S1 and Table S1. See DOI: 10.1039/c7ra02561k degradation, and other processes. ${ }^{7-9}$ Currently, in China, the main function of WWTPs is to remove excess nitrogen and phosphorus from water using functional microorganisms such as nitrifying bacteria, denitrifying bacteria and phosphorusaccumulating organisms (PAOs). ${ }^{\mathbf{1 0 1 1}}$ Roxarsone in livestock and poultry wastewater enters WWTPs, where it affects the performance of biological nitrogen and phosphorus removal. Previous studies on the impacts of roxarsone on bioreactor performance mostly concentrated on pure-medium or singleoperating mode. For example, Chen (2007) investigated the effect of roxarsone on microbial activities in soil and revealed that the presence of roxarsone seriously inhibited the processes of ammonification and nitrification. ${ }^{12}$ A recent study showed that roxarsone had a significant inhibitory effect on the removal of chemical oxygen demand (COD), anaerobic phosphate release and aerobic phosphorus uptake when the concentration of roxarsone was more than $40 \mathrm{mg} \mathrm{L}^{-1}$ in the enhanced biological phosphorus removal (BPR) process. ${ }^{1}$ Liu et al. (2014) reported the fate of roxarsone during the biological nitrogen removal process in a wastewater treatment system and found negligible roxarsone removal during the biological nitrogen removal process; this result was attributed to the emergence of a small amount of 3-amino-4-hydroxyphenylarsonic acid (HAPA) and inorganic arsenic. ${ }^{6}$ Although some efforts have been devoted to the effect of roxarsone on biological nitrogen or phosphate removal in wastewater systems, these investigations were all one-dimensional studies. In fact, the removal of organic matter, BNR and BPR should be considered simultaneously in 
a real WWTP. However, the chronic and acute impacts of roxarsone on biological nutrient removal (BNR) have rarely been explored until now. In addition, the effects of roxarsone on the biochemical metabolism of substances, the activities of key enzymes, and the relative abundance of microbes are scarcely documented in the literature.

The aim of this paper is to systematically evaluate the potential acute and chronic toxicities of roxarsone on the performance of BNR and the associated mechanism. First, the short-term and long-term effects of roxarsone on BNR performance were investigated. Second, the details of how roxarsone affects BNR were investigated from the aspects of changes in nutrients during one cycle, production and degradation of intracellular polymers, and the surface integrity of activated sludge. Third, the activities of key enzymes responsible for biological nitrogen and phosphorus removal were compared in the presence of different concentrations of roxarsone. Finally, the relative abundances of functional microorganisms [PAOs, glycogen-accumulating organisms (GAOs), ammonia-oxidizing bacteria (AOB), and nitrite-oxidizing bacteria (NOB)] at different roxarsone concentrations were compared. The findings obtained in this work might provide insights into the potential impacts of roxarsone on BNR and provide some guidance for the treatment of wastewater containing roxarsone in real situations.

\section{Materials and methods}

\subsection{Synthetic wastewater and inoculated sludge}

Synthetic wastewater was used in this work. Acetate and propionate are the main carbon sources in WWTP influent; thus, this study used sodium acetate and sodium propionate as carbon sources, and the initial COD concentration was maintained at $300 \pm 10 \mathrm{mg} \mathrm{L}^{-1}$. $\mathrm{NH}_{4} \mathrm{Cl}$ and $\mathrm{KH}_{2} \mathrm{PO}_{4}$ were used as sources of nitrogen and phosphorus, and the initial concentrations of $\mathrm{NH}_{4}{ }^{+}-\mathrm{N}$ and $\mathrm{PO}_{4}{ }^{3-}-\mathrm{P}$ were controlled at $30 \pm 1$ and $10 \pm 0.5 \mathrm{mg}$ $\mathrm{L}^{-1}$, respectively. Additionally, the trace elements required by microorganisms were included in the synthetic wastewater at the following concentrations based on the literature $\left(\mathrm{mg} \mathrm{L}^{-1}\right): \mathrm{FeCl}_{3}$ (0.50); $\mathrm{Al}_{2}\left(\mathrm{SO}_{4}\right)_{3} 18 \mathrm{H}_{2} \mathrm{O}(0.25) ; \mathrm{ZnSO}_{4} \cdot 7 \mathrm{H}_{2} \mathrm{O}(0.11) ; \mathrm{MnSO}_{4} \mathrm{H}_{2} \mathrm{O}$ (0.05); $\mathrm{CoSO}_{4} 6 \mathrm{H}_{2} \mathrm{O}(0.05) ; \mathrm{NiCl}_{2} 6 \mathrm{H}_{2} \mathrm{O}(0.05) ;\left(\mathrm{NH}_{4}\right)_{6} \mathrm{Mo}_{7} \mathrm{O}_{24} \cdot 4 \mathrm{H}_{2} \mathrm{O}$ (0.05); $\mathrm{H}_{3} \mathrm{BO}_{4}$ (0.05); and $\mathrm{CuCl}_{2}(0.05){ }^{6}$

In this experiment, the inoculated sludge used was taken from the bioreactor of a local WWTP in Haikou, Hainan province. The inoculated sludge was first pre-cultured with synthetic wastewater at $20{ }^{\circ} \mathrm{C}$; the concentration of mixed liquid-suspended solids in the wastewater was maintained at $2500 \pm 50 \mathrm{mg} \mathrm{L}^{-1}$, and the $\mathrm{pH}$ was controlled at $7.0 \pm 0.5 \mathrm{using}$ an autotitrator.

\subsection{Short-term effect of roxarsone on BNR performance}

In this work, five $10.0 \mathrm{~L}$ sequencing batch reactors (SBRs) were used to assess the potential impact of roxarsone on BNR performance. The SBRs were operated for three cycles per day, and each cycle lasted $8 \mathrm{~h}$ (90 min anaerobic phase $+150 \mathrm{~min}$ oxic phase +120 min anoxic phase +30 min settling and decanting + 90 min idle period). After the settling phase, $6.6 \mathrm{~L}$ of supernatant was discharged and replaced with the same volume of synthetic feeding medium, resulting in a hydraulic retention time of $12 \mathrm{~h}$. At the same time, $0.625 \mathrm{~L}$ of slurry mixture was discharged at the end of the oxic stage but before the anoxic phase to control the sludge retention time to $16 \mathrm{~d}$. Despite the relatively high roxarsone concentration in animal wastewater, limited information is available on roxarsone in the wastewater treatment process. The actual roxarsone concentration in animal wastewater has rarely been reported. Liu et al. (2014) used $80 \mathrm{mg} \mathrm{L}^{-1}$ roxarsone to explore the toxic effects of roxarsone on microorganisms. ${ }^{6}$ Based on the reference, the concentration of roxarsone increased properly because of the extensive production and use of roxarsone. Thus, different doses of roxarsone were added to the SBRs at the initial stage of anaerobic treatment to control the concentration of roxarsone to $30,60,90$, and $120 \mathrm{mg} \mathrm{L}^{-1}$. One SBR without roxarsone served as the control experiment. During the anaerobic and anoxic phases, the sludge and roxarsone were mixed with a mixer at a speed of $120 \mathrm{rpm}$ to allow full exposure. Triplicate samples were taken from each reactor at different stages for measurement.

\subsection{Long-term effect of roxarsone on BNR performance}

To investigate the long-term effects of the presence of roxarsone on BNR performance, five 10.0 L SBR experiments were conducted. The operating mode of the reactor was similar to that described in Section 2.2. The reactors were continuously operated for $120 \mathrm{~d}$, and the effluent was monitored daily. When the reactor was stable, the changes in phosphate, nitrate nitrogen, nitrite nitrogen, organic matter, intracellular polymers [polyhydroxyalkanoate (PHA) and glycogen], lactate dehydrogenase (LDH) release, reactive oxygen species (ROS), and the activities of key enzymes were detected to reflect the long-term impact of roxarsone on BNR.

\subsection{Assessing the impact of roxarsone on BNR in a livestock and poultry breeding wastewater treatment station}

A small-scale study was performed in a livestock and poultry breeding wastewater treatment station (around $600 \mathrm{~m}^{3} \mathrm{~d}^{-1}$ ) located in Hainan province (China). The wastewater treatment station operated as a continuous-flow stirred-tank reactor with anaerobic/aerobic/anoxic phases. The basic characteristics of wastewater from poultry farming are as follows: COD, 350$600 \mathrm{mg} \mathrm{L}{ }^{-1} ; \mathrm{NH}_{4}{ }^{+}-\mathrm{N}, 81-123 \mathrm{mg} \mathrm{L}^{-1} ; \mathrm{PO}_{4}{ }^{3}-\mathrm{P}, 24-49 \mathrm{mg} \mathrm{L}^{-1}$; and roxarsone, $30.2-61.5 \mathrm{mg} \mathrm{L}^{-1}$. The hydraulic retention time (HRT) and sludge retention time (SRT) were maintained at $12 \mathrm{~h}$ and $15 \mathrm{~d}$, respectively.

\subsection{Chemical and biological analysis}

Samples taken were immediately filtered through a $0.45 \mu \mathrm{m}$ cellulose nitrate membrane, and the filtrate was used to monitor $\mathrm{NH}_{4}{ }^{+}-\mathrm{N}, \mathrm{NO}_{3}{ }^{-}-\mathrm{N}, \mathrm{NO}_{2}{ }^{-}-\mathrm{N}, \mathrm{PO}_{4}{ }^{3-}-\mathrm{P}$, and COD. The sludge was used for the determination of PHA and glycogen.

Determinations of total suspended solids (TSS), volatile suspended solids (VSS), $\mathrm{NH}_{4}{ }^{+}-\mathrm{N}, \mathrm{NO}_{3}{ }^{-}-\mathrm{N}, \mathrm{NO}_{2}{ }^{-}-\mathrm{N}, \mathrm{PO}_{4}{ }^{3-}-\mathrm{P}$, and COD content were performed according to the standard methods. ${ }^{13}$ Total nitrogen was detected using an alkaline potassium persulfate digestion UV spectrophotometric method. ${ }^{14,15}$ 
PHA was calculated as the sum of poly- $\beta$-hydroxybutyrate, poly-3-hydroxyvalerate and poly-3-hydroxy-2-methylvalerate, and PHA was determined by gas chromatography; the detailed methods of determination are described in the literature. ${ }^{7}$ Glycogen was detected using the phenol sulfuric acid method. ${ }^{\mathbf{1 6}}$

Exopolyphosphatase (PPX) and polyphosphate kinase (PPK) are closely related to BPR and are responsible for anaerobic phosphorus release and phosphorus uptake. ${ }^{17,18}$ The analyses of PPX and PPK are described in the literature. ${ }^{19}$ The integrity of the cell membrane was determined using a cytotoxicity detection kit (LDH release assay) according to the literature. ${ }^{20}$

ROS production was measured by an established fluorescence assay. ${ }^{20}$ The cell membrane integrity and cell viability of activated sludge were respectively measured by a cytotoxicity detection kit (LDH release assay; Roche Molecular Biochemicals) and a cell counting kit-8 (cell proliferation assay; Dojindo) according to the manufacturer's instructions. ${ }^{20}$

Ammonia monooxygenase (AMO), nitrite oxidoreductase (NOR), nitrate reductase (NR) and nitrite reductase (NIR) are the key enzymes in the BNR process, and their detailed testing methods are described in the literature. ${ }^{20}$

Fluorescence in situ hybridization (FISH) was used to quantify the relative abundances of PAO and GAO in the presence of roxarsone; detailed analysis procedures can be found in the literature. ${ }^{18}$ Briefly, the sludge samples were treated with $4 \%$ formaldehyde in the later stage of the anaerobic reactor and then fixed for $20 \mathrm{~h}$ to improve the penetration of the oligonucleotide probe. Cell samples were attached to poly-L-lysinecoated slides and dehydrated with ethanol. Subsequent hybridization and lotion procedures were the same as those in the references. Quantitative analysis of FISH was conducted using Image-pro Plus 7.0 Software.

\subsection{Statistical analysis}

All experiments were repeated three times. Analysis of variance was employed to evaluate the significance of results, and $p<$ 0.05 was considered to be statistically significant.

\section{Results and discussion}

\subsection{Acute effect of roxarsone on BNR}

Microbial responses to changes in the external environment can reflect microbial adaptability. Fig. 1 shows the acute effect of roxarsone on BNR. As shown in Fig. 1, the removal efficiencies for $\mathrm{COD}, \mathrm{PO}_{4}{ }^{3-}-\mathrm{P}$ and $\mathrm{TN}$ in the control were $92.4 \%, 89.7 \%$ and $85.6 \%$, respectively. When the roxarsone concentration was $30 \mathrm{mg} \mathrm{L}^{-1}$, the removal efficiencies for COD, $\mathrm{PO}_{4}{ }^{3-}-\mathrm{P}$ and $\mathrm{TN}$ were almost unaffected. However, the removal efficiencies for $\mathrm{COD}, \mathrm{PO}_{4}{ }^{3-}-\mathrm{P}$, and TN were greatly affected when the concentration of roxarsone was above $60 \mathrm{mg} \mathrm{L}^{-1}$; the removal efficiencies for $\mathrm{COD}, \mathrm{PO}_{4}{ }^{3-}-\mathrm{P}$, and $\mathrm{TN}$ decreased from $86.5 \%$, $78.8 \%$ and $82.6 \%$ to $75.6 \%, 68.8 \%$, and $62.8 \%$, respectively. These experimental results clearly show that the effect of roxarsone on BNR was dose-dependent. The effect of a low dosage of roxarsone on BNR was not obvious, whereas high levels of roxarsone seriously inhibited BNR efficiency.

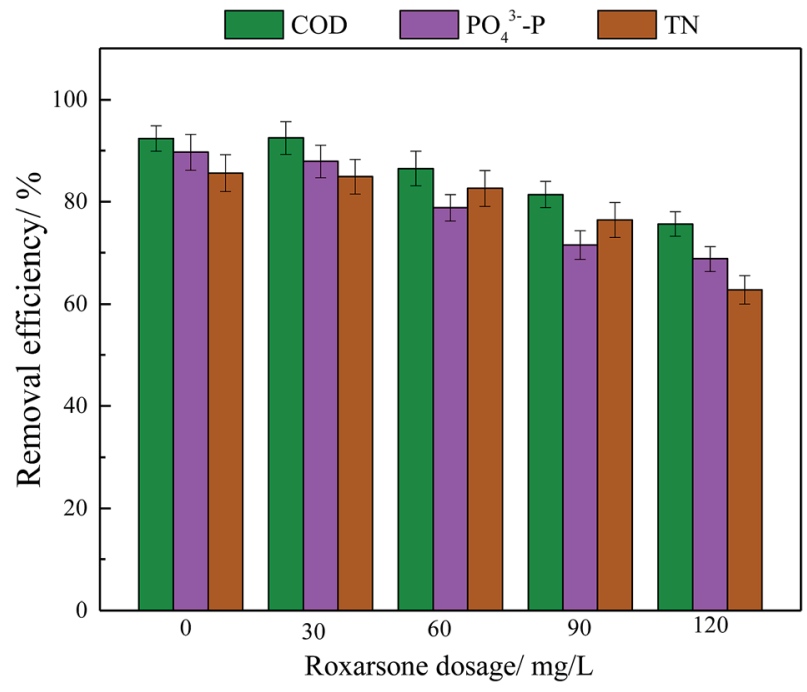

Fig. 1 Effects of short-term exposure to roxarsone on biological nitrogen and phosphorus removal from wastewater. Error bars represent standard deviations of triplicate measurements.

As the actual operation of a WWTP is long-term, it is necessary to explore the long-term impact of roxarsone on BNR performance. As shown in Table 1, the levels of nutrients in the effluent were similar for low concentrations of roxarsone (e.g., 0 and $30 \mathrm{mg} \mathrm{L}^{-1}$ ). However, when the roxarsone concentration was high, the concentration of nutrient in the effluent greatly increased, suggesting that the BNR efficiency was seriously inhibited. For instance, the levels of $\mathrm{NO}_{3}{ }^{-}-\mathrm{N}$ and $\mathrm{PO}_{4}{ }^{3-}-\mathrm{P}$ increased from 1.35 and $1.03 \mathrm{mg} \mathrm{L}^{-1}$ to 4.35 and $8.12 \mathrm{mg} \mathrm{L}^{-1}$, respectively, when the concentration of roxarsone increased from 0 to $120 \mathrm{mg} \mathrm{L}^{-1}$. The BPR efficiency was only $18.8 \%$ when the roxarsone concentration was $120 \mathrm{mg} \mathrm{L}^{-1}$, indicating the system collapse of BPR. It should be noted that with increasing roxarsone concentration, the VSS/TSS ratio in the reactor showed a decreasing trend. The VSS/TSS ratio decreased from 0.68 to 0.49 when the level of roxarsone increased from 0 to $120 \mathrm{mg} \mathrm{L}^{-1}$. The decrease in VSS/TSS implied that the content of organic matter in the reaction system decreased, and the amount of microorganisms in the sludge decreased. ${ }^{21-25}$ The above experimental data indicate that the presence of high concentrations of roxarsone gave severely inhibited BNR, whereas low concentrations of roxarsone did not significantly impact BNR performance.

To clarify the mechanism of how roxarsone affects the removal of nitrogen and phosphorus is of great significance for the treatment of wastewater containing roxarsone. Therefore, in the following section, we focus on how roxarsone affects BNR performance from the aspects of intermediate metabolite changes, key enzyme activities, and the surface integrity of sludge.

\subsection{Effects of roxarsone on the conversion of metabolic intermediates in the BNR process}

The investigation of the transformation of intermediate products in microbial metabolism is helpful to understand the effects of 
Table 1 Summary of reactor performance in the presence of different levels of roxarsone during steady-state operation ${ }^{a}$

\begin{tabular}{lccrr}
\hline & $0 \mathrm{mg} \mathrm{L}^{-1}$ & $30 \mathrm{mg} \mathrm{L}^{-1}$ & $60 \mathrm{mg} \mathrm{L}^{-1}$ & $90 \mathrm{mg} \mathrm{L}^{-1}$ \\
\hline $\mathrm{COD}\left(\mathrm{mg} \mathrm{L}^{-1}\right)$ & $22.8 \pm 1.3$ & $25.5 \pm 1.8$ & $58.2 \pm 2.3$ & $85.2 \pm 3.5$ \\
$\mathrm{NH}_{4}^{+}-\mathrm{N}\left(\mathrm{mg} \mathrm{L}^{-1}\right)$ & $2.4 \pm 0.3$ & $2.1 \pm 0.4$ & $2.7 \pm 0.6$ & $3.3 \pm 0.7$ \\
$\mathrm{NO}_{2}{ }^{-}-\mathrm{N}\left(\mathrm{mg} \mathrm{L}^{-1}\right)$ & $0.24 \pm 0.05$ & $0.26 \pm 0.08$ & $0.75 \pm 0.09$ & $1.28 \pm 0.09$ \\
$\mathrm{NO}_{3}-\mathrm{N}\left(\mathrm{mg} \mathrm{L}^{-1}\right)$ & $1.21 \pm 0.06$ & $1.35 \pm 0.05$ & $2.64 \pm 0.08$ & $3.06 \pm 0.08$ \\
$\mathrm{PO}_{4}{ }^{3}-\mathrm{P}\left(\mathrm{mg} \mathrm{L}^{-1}\right)$ & $1.03 \pm 0.07$ & $1.21 \pm 0.15$ & $3.12 \pm 0.19$ & $6.8 \pm \pm 0.4$ \\
VSS/TSS & $0.68 \pm 0.05$ & $0.64 \pm 0.08$ & $0.59 \pm 0.07$ & $0.52 \pm 0.07$ \\
\end{tabular}

${ }^{a}$ Note: data were obtained during the stable operation of the SBR. The data reported are the averages and their standard deviations in triplicate tests.

changes in the external environment on BNR efficiency. Fig. 2 illustrates the effects of different concentrations of roxarsone on the transformation of $\mathrm{P}$ and $\mathrm{N}$ during steady-state operation. $\mathrm{A}$ large amount of $\mathrm{PO}_{4}{ }^{3-}-\mathrm{P}$ was released during the anaerobic phase, and the levels of $\mathrm{PO}_{4}{ }^{3-}-\mathrm{P}$ in control and $30 \mathrm{mg} \mathrm{L}^{-1}$ were $62.9 \mathrm{mg} \mathrm{L}^{-1}$ and $59.4 \mathrm{mg} \mathrm{L}^{-1}$, respectively, at the end of the anaerobic phase. The experimental results indicated that the low concentration of roxarsone had little effect on anaerobic phosphorus release. However, when the roxarsone concentration was $120 \mathrm{mg} \mathrm{L}^{-1}$, the concentration of $\mathrm{PO}_{4}{ }^{3-}-\mathrm{P}$ at the end of the anaerobic phase was only $44.8 \mathrm{mg} \mathrm{L}^{-1}$, much lower than that in the blank and the group with a roxarsone concentration of $30 \mathrm{mg}$ $\mathrm{L}^{-1}$. In the subsequent oxic phase, PAOs cultured in the sludge assimilated excessive phosphorus to achieve phosphate removal. The aerobic uptakes of phosphorus in the blank group and the group containing $30 \mathrm{mg} \mathrm{L}^{-1}$ roxarsone were 58.7 and $52.8 \mathrm{mg}$
$\mathrm{L}^{-1}$, respectively; however, the aerobic phosphorus uptake in the group containing $120 \mathrm{mg} \mathrm{L}^{-1}$ roxarsone was only $36.4 \mathrm{mg} \mathrm{L}^{-1}$, which was about 0.62 times that of the blank. The decreased aerobic phosphorus uptake led to an increased water phosphorus content, thereby causing phosphorus system collapse. These data clearly suggest that the presence of a high concentration of roxarsone inhibited anaerobic P release and aerobic P uptake.

Fig. 2B illustrates that roxarsone had no significant impact on the removal of ammonia, and the $\mathrm{NH}_{4}{ }^{+}-\mathrm{N}$ removal efficiencies in all reactors were approximately $92 \%$, consistent with the data in Table 1. Ammonia is first oxidized to nitrite by $\mathrm{AOB}$ and then further oxidized to nitrate by NOB; finally, nitrate and nitrite are reduced to $\mathrm{N}_{2}$ via denitrification during the subsequent anoxic phase. $^{26-28}$ The effects of a low concentration of roxarsone on the activities of $\mathrm{AOB}$ and $\mathrm{NOB}$ were not obvious; the highest concentrations of $\mathrm{NO}_{2}-\mathrm{N}$ and $\mathrm{NO}_{3}{ }^{-}-\mathrm{N}$ in the presence of $30 \mathrm{mg} \mathrm{L}^{-1}$
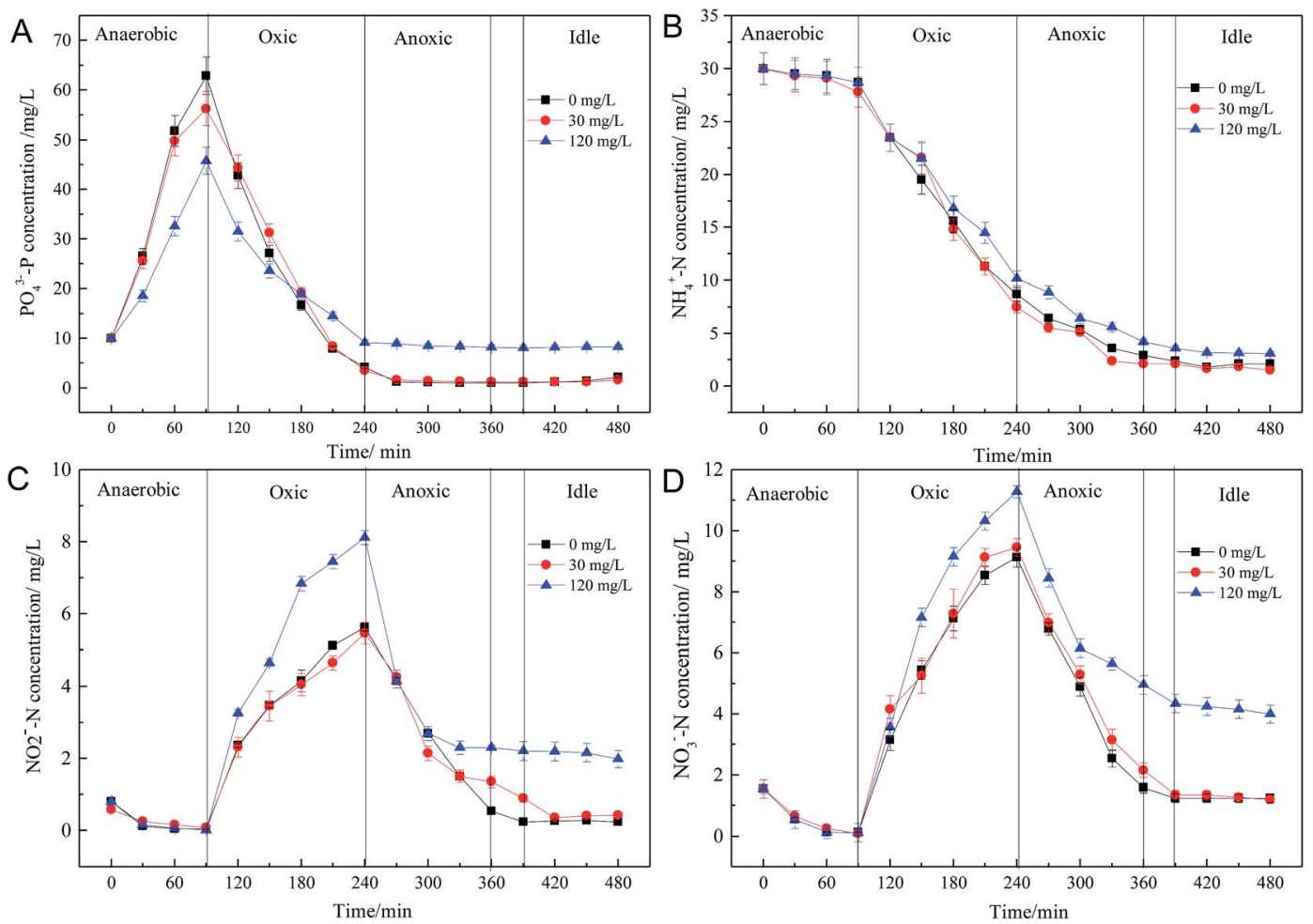

Fig. 2 Effects of roxarsone on the concentrations of (A) $\mathrm{PO}_{4}{ }^{3-}-\mathrm{P}$, (B) $\mathrm{NH}_{4}{ }^{+}-\mathrm{N}$, (C) $\mathrm{NO}_{2}{ }^{-}-\mathrm{N}$ and (D) $\mathrm{NO}_{3}{ }^{-}-\mathrm{N}$ during a typical period at different roxarsone concentrations. Error bars represent standard deviations of triplicate measurements. 
roxarsone were 5.47 and $9.45 \mathrm{mg} \mathrm{L}^{-1}$, respectively, similar to those in the blank. However, the highest levels of $\mathrm{NO}_{2}-\mathrm{N}$ and $\mathrm{NO}_{3}{ }^{-}-\mathrm{N}$ in the presence of $120 \mathrm{mg} \mathrm{L}^{-1}$ roxarsone were 8.12 and $12.28 \mathrm{mg} \mathrm{L}^{-1}$, respectively, much higher than those in blank, suggesting that presence of a high concentration of roxarsone significantly inhibited the nitrification and denitrification steps. The inhibitory effect of roxarsone on nitrification was less than that on denitrification, and this result was similar to that of the pollutant $\mathrm{Cd}(\mathrm{II})$ on biological denitrification reported in the literature. ${ }^{29}$ This might be attributed to the fact that the toxic effects of contaminants on nitrifying bacteria are weaker than the toxic effects on denitrifying bacteria. ${ }^{30}$ Nitrite can produce free nitrite acid (FNA) in water, which has serious toxic effects on microbial metabolism, and the concentration of FNA is directly proportional to the concentration of nitrite. ${ }^{\mathbf{8}, 31,32}$ A high concentration of FNA resulting from a high concentration of roxarsone would lead to the deterioration or even collapse of BNR. The facts described above indicate that high levels of roxarsone have a negative effect on phosphorus release and uptake, nitrification and denitrification.

The supply and consumption of energy is an important factor affecting nitrogen and phosphorus removal. ${ }^{33}$ Nitrification is an autotrophic process; however, the microorganisms involved in the biological denitrification process are heterotrophic bacteria, which require electron donors to provide electrons to drive the denitrification process. ${ }^{34}$ In the process of BPR, PAOs can absorb the available carbon sources in the water and synthesize PHA under anaerobic conditions. At the same time, the polyphosphate in microbial cells is degraded for energy production, releasing a large amount of phosphate. Glycogen is also degraded to provide reducing power under anaerobic conditions. In the subsequent aerobic or anoxic phase, the PHA synthesized in the anaerobic period is degraded to produce energy for aerobic phosphorus uptake, glycogen replenishment and microbial growth. ${ }^{35}$ Meanwhile, denitrifying bacteria in the anoxic phase also need energy for denitrification, and this energy can also be derived from the degradation of PHA.

Fig. 3 displays the variations in intracellular polymers during a single cycle at different levels of roxarsone. It was found that influent COD was consumed rapidly, and the removal efficiency of COD when the concentration of roxarsone was $30 \mathrm{mg} \mathrm{L}^{-1}$ was similar compared to that in the control. However, when the concentration of roxarsone was increased to $120 \mathrm{mg} \mathrm{L}^{-1}$, the consumption of COD was severely inhibited, and the resultant concentration of COD in the effluent was more than $100 \mathrm{mg} \mathrm{L}^{-1}$. PHA was synthesized in the anaerobic phase and decomposed in the subsequent aerobic and/or anoxic periods. The maximum amount of PHA in the blank was 3.8 mmol-C $\mathrm{g}^{-1} \mathrm{VSS}$, and the maximum amount of PHA was 3.7 mmol-C $\mathrm{g}^{-1}$ VSS when the concentration of roxarsone was $30 \mathrm{mg} \mathrm{L}^{-1}$. There was no significant difference in the amount of PHA synthesized $(p>0.05)$, indicating that the low concentration of roxarsone had little inhibitory effect on the synthesis of PHA (Table S1†). However, when the concentration of roxarsone was $120 \mathrm{mg} \mathrm{L}^{-1}$, the synthesis of PHA was only 2.8 mmol-C $\mathrm{g}^{-1}$ VSS, which was about 0.73 times that in the control. These experimental results clearly showed that the high concentration of roxarsone seriously inhibited the synthesis of PHA. The reduction in the synthesis of PHA resulted in less energy consumption in subsequent oxic or anoxic stages, limiting the processes of aerobic phosphorus uptake and denitrification. On the other hand, glycogen is also an important energy storage material in cells. Under anaerobic conditions, glycogen was degraded to produce reducing power for the synthesis of PHA. During the subsequent aerobic conditions, glycogen was replenished by the consumption of PHA. The lowest concentration of glycogen in the blank was 2.5 mmol-C $\mathrm{g}^{-1}$ VSS. When the concentration of roxarsone increased to $120 \mathrm{mg} \mathrm{L}^{-1}$, the lowest content of glycogen decreased to 2.09 mmol-C $\mathrm{g}^{-1} \mathrm{VSS}$, implying that the high concentration of roxarsone decreased the content of glycogen. It is well known that there are two kinds of microorganisms, PAOs and GAOs, in the BRP system, and glycogen is the main carbon source. GAOs are microorganisms that can compete with PAOs for the limited carbon source while making no contribution to BPR. The synthesis and degradation of glycogen is mainly associated with the activities of GAOs, and a higher transformation of glycogen corresponds to higher GAO metabolism. ${ }^{36}$ A high transformation of glycogen was observed when the concentration of roxarsone was high $\left(120 \mathrm{mg} \mathrm{L}^{-1}\right)$, indicating that the relative abundance of GAO in the reactor was large. The high abundance of GAOs was also one of the reasons for the decrease in phosphorus removal efficiency when the concentration of roxarsone was high.

\subsection{Effects of roxarsone on the activities of key enzymes and the microbial community during the BNR process}

The removal of nitrogen and phosphorus from wastewater is regulated by biological processes, which are dominated by
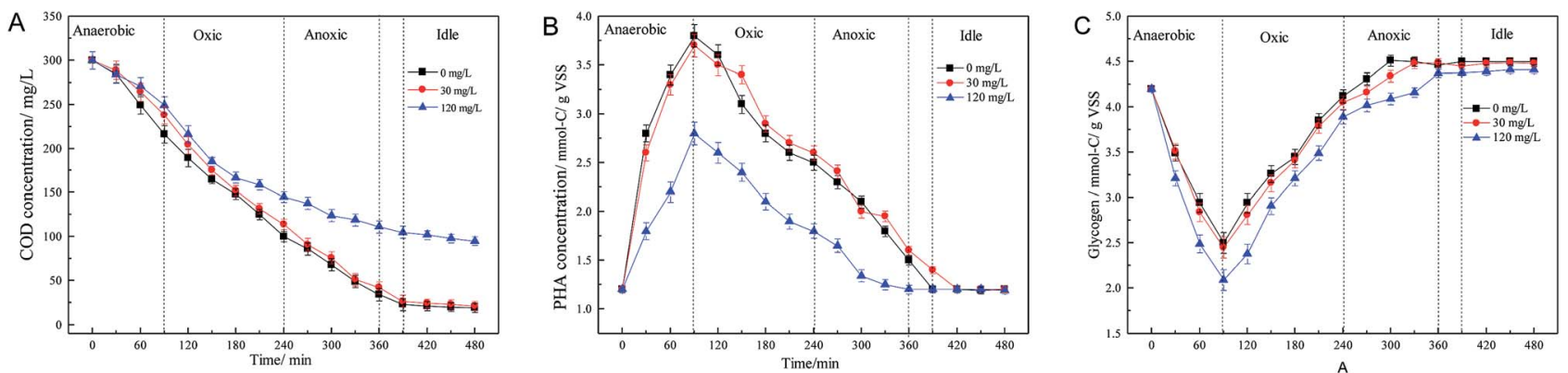

Fig. 3 Effects of roxarsone on the concentrations of (A) COD, (B) PHA, and (C) glycogen during a single cycle at different roxarsone concentrations. Error bars represent standard deviations of triplicate measurements. 
Table 2 Effects of roxarsone on the activities of key enzymes in biological nitrogen and phosphorus removal ${ }^{a}$

\begin{tabular}{|c|c|c|c|c|c|c|}
\hline & PPX & PPK & AMO & NOR & NR & NIR \\
\hline $30 \mathrm{mg} \mathrm{L}^{-1}$ & $0.022 \pm 0.002$ & $0.238 \pm 0.016$ & $0.023 \pm 0.003$ & $0.072 \pm 0.006$ & $0.031 \pm 0.003$ & $0.228 \pm 0.021$ \\
\hline
\end{tabular}

${ }^{a}$ Error bars represent standard deviations of triplicate measurements. The unit of PPX is $\mu \mathrm{mol} p$-nitrophenol/(min $\mathrm{mg}$ protein). The unit of PPK is $\mu \mathrm{mol} \mathrm{NADPH} /(\mathrm{min} \mathrm{mg}$ protein). The units of key enzymes responsible for biological nitrogen removal are $\mu \mathrm{mol}$ nitrite/(min $\mathrm{mg}$ protein).

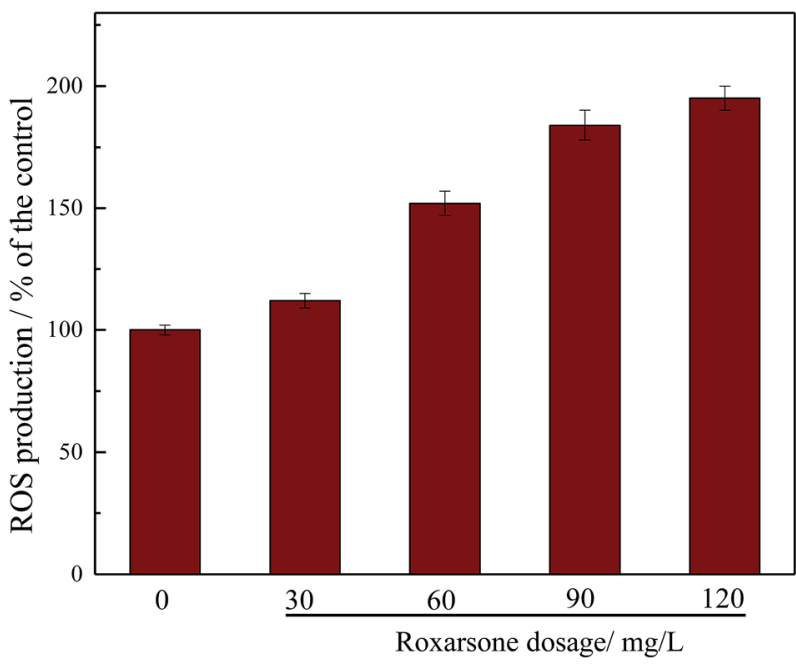

Fig. 4 Effect of roxarsone on intracellular ROS production. Error bars represent standard deviations of triplicate determinations.

many key enzymes. ${ }^{18,22}$ The release of anaerobic phosphate and the absorption of phosphate are closely related to the activities of PPX and PPK, respectively. ${ }^{19,20}$ In contrast, the BNR process mainly depends on the activities of AMO, NOR, NR and NIR. ${ }^{37}$ Table 2 summarizes the effects of different levels of roxarsone on the activities of key enzymes responsible for BNR and BPR. As shown in Table 2, when the level of roxarsone was $30 \mathrm{mg} \mathrm{L}^{-1}$, the activities of the key enzymes were similar to those in the control, and these results were consistent with Table 1 and Fig. 2. However, when the concentration of roxarsone increased to $120 \mathrm{mg} \mathrm{L}^{-1}$, the enzyme activities were severely inhibited. For example, the respective activities of PPX and PPK were 0.015 and $0.189 \mu \mathrm{mol} \mathrm{NADPH} /(\mathrm{min} \mathrm{mg}$ protein), much lower than those in the control. The decreases in the activities of PPX and PPK indicated that the amounts of anaerobic phosphorus release and $\mathrm{P}$ uptake decreased, which led to the decrease in BPR. This was consistent with the variation in phosphate in a typical cycle (Fig. 2). Similar experimental results were also found for the activities of key enzymes responsible for the processes of nitrification and denitrification.

It was found that the ROS produced by exogenous substances was capable of inhibiting the key enzymes involved in BNR. ${ }^{38,39}$ Fig. 4 shows the effect of roxarsone on intracellular ROS production. As shown in Fig. 4, ROS production increased with increasing roxarsone concentration. When the level of roxarsone was $120 \mathrm{mg} \mathrm{L}^{-1}$, the intracellular ROS production was $195 \%$ that in the control. High levels of ROS production may significantly inhibit cell membrane or cytoplasmic proteins. ${ }^{40,41}$ The high level of intracellular ROS production induced by the high concentration of roxarsone also explains the deterioration of biological nitrogen and phosphorus removal. The effect of roxarsone on the release of LDH was further studied, and the results are displayed in Fig. 5. There was no measured difference in the release of LDH under different concentrations of roxarsone, which suggested that the ROS produced in this experiment did not damage the sludge microbial cell membrane.

The identification of the microbial community is helpful to understand the effect of exogenous pollutants on biological nitrogen and phosphorus removal. Table 3 compares the relative abundances of key microbial communities at different levels of roxarsone. With increasing roxarsone concentration, the relative abundance of PAOs showed a decreasing trend, while the relative abundance of GAOs increased. For example, when the concentration of roxarsone increased from 0 to $120 \mathrm{mg} \mathrm{L}^{-1}$, the abundance of PAOs decreased from $19.4 \%$ to $10.3 \%$, while the relative abundance of GAOs increased from $10.2 \%$ to $18.4 \%$. The experimental data are consistent with the concentrations of phosphate, $\mathrm{NO}_{2}{ }^{-}-\mathrm{N}$ and $\mathrm{NO}_{3}{ }^{-} \mathrm{N}$ in the effluent.

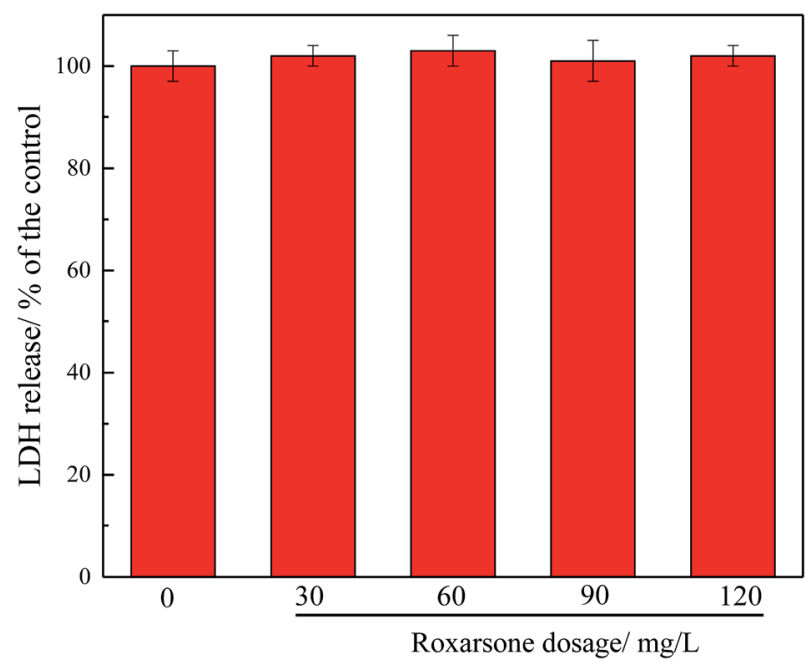

Fig. 5 Effect of roxarsone on LDH release. Error bars represent standard deviations of triplicate determinations. 
Table 3 Comparison of relative abundances of key microbial communities under different concentrations of roxarsone ${ }^{a}$

\begin{tabular}{lllll}
\hline & $\mathrm{PAO} / \%$ & $\mathrm{GAO} / \%$ & $\mathrm{AOB} / \%$ & $\mathrm{NOB} / \%$ \\
\hline $0 \mathrm{mg} \mathrm{L}^{-1}$ & $19.4 \pm 0.6$ & $10.2 \pm 0.3$ & $16.5 \pm 1.2$ & $20.5 \pm 1.5$ \\
$30 \mathrm{mg} \mathrm{L}^{-1}$ & $18.6 \pm 0.3$ & $11.2 \pm 0.5$ & $16.3 \pm 1.3$ & $20.2 \pm 1.6$ \\
$60 \mathrm{mg} \mathrm{L}^{-1}$ & $16.5 \pm 0.5$ & $12.6 \pm 0.8$ & $15.2 \pm 0.9$ & $19.5 \pm 1.4$ \\
$90 \mathrm{mg} \mathrm{L}^{-1}$ & $12.5 \pm 0.4$ & $15.9 \pm 0.9$ & $15.0 \pm 0.8$ & $18.4 \pm 1.4$ \\
$120 \mathrm{mg} \mathrm{L}^{-1}$ & $10.3 \pm 0.3$ & $18.4 \pm 1.1$ & $14.8 \pm 1.1$ & $15.2 \pm 1.6$
\end{tabular}

${ }^{a}$ Microbiological sampling was conducted during the stable operation of the reactor. Error bars represent standard deviations of triplicate determinations.

\subsection{Assessing the impact of roxarsone on BNR in a livestock and poultry breeding wastewater treatment station}

The effect of roxarsone on BNR performance was studied in a livestock and poultry breeding wastewater treatment station. As shown in Fig. $\mathbf{S} 1, \uparrow$ the presence of roxarsone in livestock and poultry breeding wastewater had a serious inhibitory effect on nutrient removal. The removal efficiencies of $\mathrm{COD}, \mathrm{NH}_{4}{ }^{+}-\mathrm{N}, \mathrm{TN}$ and TP were only $78.6 \%, 86 \%, 76 \%$, and $69 \%$, respectively. The above experimental results are similar to those shown in Table 2 obtained from the laboratory-scale experiment. The removal efficiency of total nitrogen and total phosphorus indicated a deterioration of waterbody, which in turn threatened the ecological environment. The impact of roxarsone on nutrient removal in pilot-scale WWTPs will be the focus of our research in the future.

\section{Conclusion}

In this work, the short-term and long-term exposure to low concentrations of roxarsone had no influence on BNR, while high concentrations of roxarsone (e.g., $\left.120 \mathrm{mg} \mathrm{L}^{-1}\right)$ seriously inhibited BNR performance. Mechanistic investigation revealed that high concentrations of roxarsone can reduce the yield of intracellular PHA while promoting glycogen metabolism. In addition, the high concentration of roxarsone was capable of inhibiting the activities of the key enzymes responsible for BNR, leading to increases in nitrogen and phosphorus in the effluent. Identification of the microbial community showed that when the roxarsone concentration was $120 \mathrm{mg} \mathrm{L}^{-1}$, the relative abundances of PAO, AOB and NOB were $10.3 \%, 14.8 \%$ and $15.2 \%$, respectively, much lower than those in the control. In contrast, the relative abundance of GAOs $(18.4 \%)$ was higher than in the control. The experimental results were consistent with the levels of nitrogen and phosphorus in the effluent.

\section{Acknowledgements}

This research was financially supported by National Natural Science Foundation of Hainan Province (417146 and 817324), the Colleges and Universities Scientific Research Projects of the Education Department of Hainan Medical University (HYCX2016046).

\section{References}

1 Q. Guo, L. Liu, Z. Hu and G. Chen, Chemosphere, 2013, 92, 138-142.

2 I. Cortinas, J. A. Field, M. Kopplin, J. R. Garbarino, A. J. Gandolfi and R. Sierra-Alvarez, Environ. Sci. Technol., 2006, 40, 2951-2957.

3 L. Yao, G. Li and Z. Dang, Chin. J. Appl. Ecol., 2006, 7, 19891992, in Chinese.

4 R. Sierra-Alvarez, I. Cortinas, U. Yenal and J. A. Field, Appl. Environ. Microbiol., 2004, 70, 5688-5691.

$5 \mathrm{~J}$. Hu, Z. Tong, Z. Hu, G. Chen and T. Chen, J. Colloid Interface Sci., 2012, 377, 355-361.

6 H. Liu, G. Wang, J. Ge, L. Liu and G. Chen, Chem. Eng. J., 2014, 235, 500-505.

7 H. An, X. Li, Q. Yang, D. Wang, T. Xie, J. Zhao, Q. Xu, F. Chen, Y. Zhong, Y. Yuan and G. Zeng, J. Hazard. Mater., 2017, 322, 445-453.

8 J. Zhao, D. Wang, X. Li, Q. Yang, H. Chen, Y. Zhong and G. Zeng, Water Res., 2015, 78, 111-120.

9 C. Zhao, W. Ding, F. Chen, C. Cheng and Q. Shao, Bioresour. Technol., 2014, 155, 34-40.

10 A. Chen, Y. Chen, C. Ding, H. Liang and B. Yang, RSC Adv., 2015, 5, 59326-59334.

11 M. Lunau, M. Voss, M. Erickson, C. Dziallas, K. Casciotti and H. Ducklow, Environ. Microbiol., 2013, 15, 1492-1504.

12 D. Chen, Study on ecological toxicity of roxazate to soil, Yangzhou University, Yangzhou, 2007.

13 APHA, Standard Methods for the Examination of Water and Wastewater, American Public Health Association, Washington, DC, 20th edn, 1998.

14 C. Zhao, Y. Cao, Z. Ma and Q. Shao, Biomass Bioenergy, 2017, 98, 61-69.

15 C. Zhao, Q. Shao, Z. Ma, B. Li and X. Zhao, Ind. Crops Prod., 2016, 83, 86-93.

16 J. Zhao, Q. Yang, X. Li, D. Wang, H. An, T. Xie, Q. Xu, Y. Deng and G. Zeng, Int. Biodeterior. Biodegrad., 2015, 104, 283-289.

17 J. Zhao, C. Zhang, D. Wang, X. Li, H. An, T. Xie, F. Chen, Q. Xu, Y. Sun, G. Zeng and Q. Yang, ACS Sustainable Chem. Eng., 2016, 4, 4675-4684.

18 J. Zhao, D. Wang, X. Li, G. Zeng and Q. Yang, RSC Adv., 2016, 6, 86165-86173.

19 Y. Chen, B. Li, L. Ye and Y. Peng, Biochem. Eng. J., 2015, 93, 235-242.

20 X. Zheng, R. Wu and Y. Chen, Environ. Sci. Technol., 2011, 45, 2826-2832.

21 T. Mino, M. C. M. Van Loosdrecht and J. J. Heijnen, Water Res., 1998, 32, 3193-3207.

22 A. Oehmen, P. C. Lemos, G. Carvalho, Z. Yuan, J. Keller, L. L. Blackall and M. A. Reis, Water Res., 2007, 41, 2271-2300.

23 D. Wang, Q. Xu, Q. W. Yang, H. Chen, X. Li, D. Liao, G. Yang, Q. Yang and G. Zeng, Biochem. Eng. J., 2014, 87, 15-24.

24 D. B. Wang, X. M. Li, Q. Yang, G. M. Zeng, D. X. Liao and J. Zhang, Bioresour. Technol., 2008, 99, 5466-5473.

25 H. Chen, Y. Liu, B. J. Ni, Q. Wang, D. Wang, C. Zhang, X. Li and G. Zeng, Biochem. Eng. J., 2016, 113, 114-122. 
26 M. K. Winkler, Q. H. Le and E. I. Volcke, Environ. Sci. Technol., 2015, 49, 11003-11010.

27 B. Ma, S. Wang, S. Cao, Y. Miao, F. Jia, R. Du and Y. Peng, Bioresour. Technol., 2016, 200, 981-990.

28 C. Zhao, Z. Ma, Q. Shao, B. Li, J. Ye and H. Peng, Energy Fuels, 2016, 30, 1154-1161.

29 H. B. Chen, D. B. Wang, X. M. Li, Q. Yang, K. Luo, G. M. Zeng and M. L. Tang, Chemosphere, 2014, 117, 27-32.

30 Y. M. Kim, D. Park, D. S. Lee and J. M. Park, J. Hazard. Mater., 2008, 152, 915-921.

31 X. Li, J. Zhao, D. Wang, Q. Yang, Q. Xu, Y. Deng, W. Yang and G. Zen, Chemosphere, 2016, 144, 160-167.

32 C. Zhao, Q. Shao, B. Li and W. Ding, Energy Fuels, 2014, 28, 6392-6397.

33 T. Cai, S. Y. Park and Y. Li, Renewable Sustainable Energy Rev., 2013, 19, 360-369.
34 P. T. Kelly and Z. He, Bioresour. Technol., 2014, 153, 351-360. 35 W. Zeng, J. Zhang, A. Wang and Y. Peng, Bioresour. Technol., 2016, 207, 322-331.

36 G. Carvalho, P. C. Lemos, A. Oehmen and M. A. Reis, Water Res., 2007, 41, 4383-4396.

37 L. Y. Juliette, M. R. Hyman and D. J. Arp, Appl. Environ. Microbiol., 1993, 59, 3718-3727.

38 Y. Chen, H. Chen, X. Zheng and H. Mu, J. Hazard. Mater., 2012, 239, 88-94.

39 N. Bayat, K. Rajapakse, R. Marinsek-Logar, D. Drobne and S. Cristobal, Nanotoxicology, 2014, 8, 363-373.

40 S. George, S. Pokhrel, T. Xia, B. Gilbert, Z. Ji, M. Schowalter, A. Rosenauer, R. Damoiseaux, K. Bradley, L. Mädler and A. E. Nel, ACS Nano, 2009, 4, 15-29.

41 R. Brayner, R. Ferrari-Iliou, N. Brivois, S. Djediat, M. F. Benedetti and F. Fiévet, Nano Lett., 2006, 6, 866-870. 